\title{
Environmental variations drive polyploid evolution in neotropical Eugenia species (Myrtaceae)
}

\author{
R.M. Silveira ${ }^{1}$, R.M. Machado ${ }^{2}$, E.R. Forni-Martins ${ }^{2}$, C.F. Verola $^{1}$ and \\ I.R. Costa ${ }^{1}$
}

${ }^{1}$ Laboratório de Citotaxonomia e Evolução de Plantas, Departamento de Biologia, Centro de Ciências, Universidade Federal do Ceará, Fortaleza, CE, Brasil

${ }^{2}$ Departamento de Biologia Vegetal, Instituto de Biologia,

Universidade Estadual de Campinas, Campinas, SP, Brasil

Corresponding author: I.R. Costa

E-mail: itayguara@gmail.com

Genet. Mol. Res. 15 (4): gmr15048842

Received June 2, 2016

Accepted July 12, 2016

Published October 24, 2016

DOI http://dx.doi.org/10.4238/gmr15048842

Copyright $(2016$ The Authors. This is an open-access article distributed under the terms of the Creative Commons Attribution ShareAlike (CC BY-SA) 4.0 License.

\begin{abstract}
Polyploidy is one of the most important mechanisms of speciation and diversification in plant evolution. Polyploidy results in genetic variation among individuals of the same species and even between populations, and may be responsible for differences in environmental tolerance between populations of the same species. This study determined chromosome numbers of Eugenia L. (Myrtaceae, $\mathrm{x}=11$ ) for 26 populations of 14 species by conventional cytogenetic techniques. Nine species (13 populations) were diploid $(2 n=2 x=22)$, but diploid and/or polyploid cytotypes were found in the other five species (13 populations), with $2 \mathrm{n}=33,2 \mathrm{n}=44$, and $2 \mathrm{n}=55$. Data on chromosome number/ploidy level for other Eugenia species/populations were collected from the literature and included in this cytogeographic
\end{abstract}


analysis. For each collection point (32 species and 62 populations), environmental variables were recorded using georeferencing techniques through the DIVA-GIS v.7.5 program. Environmental variables such as temperature, altitude, rainfall, solar radiation, soil type, and vegetation were analyzed with the R program, using MannWhitney and chi-square tests, principal component analysis, and graphic analyses, such as scatterplots, boxplots, and barplot. Polyploid and diploid populations had different spatial distribution patterns and were found in areas subjected to different environmental conditions. Polyploid individuals were collected from locations with more adverse environmental conditions, usually at higher elevations than the diploid individuals. Polyploidy allows species to occur at locations with varying environmental conditions. As diploidy and polyploidy occur under different environmental conditions, species with cytotypes exhibit wide environmental tolerance.

Key words: Chromosomes; Karyotype; Neotropics; Myrtaceae; Cytogeography; Polyploidy

\section{INTRODUCTION}

The existence of a given population in a particular region is determined by the tolerance of individuals within the population to a set of biotic or abiotic factors and environmental conditions that affect at least one stage of its development (Begon et al., 2007). Abiotic factors include climatic, edaphic, and hydrological factors. Conversely, biotic factors include interactions between organisms/species in an ecosystem, namely predation, parasitism, or competition (Begon et al., 2007).

The environmental tolerance range (ETR) varies between the minimum and maximum values for each environmental factor (Begon et al., 2007). The ETR may be narrower or wider depending on the species and the related environmental factors (IBGE, 2004). In this way, species with wide tolerance to various environmental factors tend to present wide geographical and ecological distribution (Aguiar and Gaglianone, 2012). ETR is not constant for all individuals, and genetic variability permits the existence of individuals that respond differently to a certain environmental factor within a population. This is better illustrated in heterogeneous habitats, in which several individuals present different adaptive strategies or phenotypical plasticity (distinct phenotypes) (Via et al., 1995).

Polyploidy promotes genetic variability between individuals or populations of a given species (Schifino-Wittmann, 2004), and co-operates with differences in ETR. Polyploidy is considered to be an important evolutionary force promoting sympatric speciation and diversification in plants, and occurs in up to $80 \%$ of angiosperms (Otto and Whitton, 2000). Polyploids are able to colonize pioneer habitats, which would permit their occurrence in different environments to the diploid parents. Sometimes, cytotypes of the same species occur in distinct geographical regions (Levin, 2002) that present ecological differences such as temperature, rainfall, and radiation levels (Otto and Whitton, 2000; Schifino-Wittmann, 2004). Polyploids may arise as the result of autopolyploidy or allopolyploidy (SchifinoWittmann, 2004). Risso-Pascotto et al. (2006) described a probable allopolyploid $(2 \mathrm{n}=6 \mathrm{x}$

Genetics and Molecular Research 15 (4): gmr15048842 
= 54) in Brachiaria brizantha (Poaceae), with a high percentage of meiotic abnormalities. This cytotype could have resulted from chromosomal doubling of a triploid derived from interspecific hydridization.

In fact, the effect of polyploidy in ecological processes is a relevant issue for ecologists, botanists, and geneticists. Johnson et al. (2003) noted that little is known about the mechanisms that maintain cytotype separation, despite their importance. The way in which polyploidy affects the tolerance of individuals to environmental factors and the geographical pattern of diploids and polyploids remain unclear (Johnson et al., 2003; Soltis et al., 2010). Researchers reinforce the importance of quantitative and statistical inferences to provide evidence of the differences between diploids and polyploids (Johnson et al., 2003).

Polyploidy affects important ecological characters in species, such as pollination, geographical distribution, life form, and growth form (Thompson et al., 2004). Due to this, we speculate that ETR would be influenced by polyploidy. Abiotic factors such as temperature and water stress modify the frequency of unreduced gametes (Ramsey and Schemske, 1998). However, it is unknown whether there is a pattern of environmental conditions that are related to the occurrence of polyploidy, or which environmental conditions influence the persistence and natural distribution of polyploids (Johnson et al., 2003). The study of widely distributed species enables us to understand how polyploidy influences the diversification and geographical distribution of closed related taxa, permitting the determination of a pattern of local environmental conditions in which the polyploids are found.

Eugenia L., which has approximately 1009 species (Govaerts et al., 2016) occurring from Mexico and the Caribbean to Argentina, is considered to be the second most diverse genus in neotropical Myrtaceae (Govaerts et al., 2016; Sobral et al., 2016) and one of the most speciose genera from tropical America. Approximately 384 species are native to Brazil (Sobral et al., 2016). Only 24 Eugenia species (2.3\% of the species diversity) have known chromosome numbers, which is a small amount considering the diversity of the genus. Analyses of the morphology of mitotic chromosomes and chromosome behavior during meiosis are scarce for Myrtaceae (Costa and Forni-Martins, 2007; Costa, 2009). Studies have noted the polyploid cytotypes in Eugenia, Myrcia DC. ex. Guill. and Psidium L. with 2x, 3x, 4x, and 6x populations (Costa and Forni-Martins, 2006a,b, 2007; Costa et al., 2008; Costa, 2009). Polyploid cytotypes are known for innumerous species, as the invasive species Euphorbia heterophylla L. (Euphorbiaceae), with $2 \mathrm{n}=14,26,28,32$, or 56 (Aarestrup et al., 2008).

In this context, the present study aimed to determine the pattern of environmental conditions and the distribution of ploidy in 32 species of Eugenia from 62 different collections distributed in eastern Brazil (Table 1). More than two populations were analyzed for some species, such as E. punicifolia (Kunth) DC., E. dysenterica DC., E. hyemalis Cambess., E. klotzschiana O. Berg, and E. pitanga (O. Berg) Kiaersk. (Table 1).

We hypothesized that polyploidy extends the tolerance of species, thus allowing the occurrence of species at different sites with wide variations in environmental conditions. We predict that polyploid species occur in environments of higher altitude, high temperature variability, low rainfall (low water availability), chemically poor, newly formed soils, and high levels of radiation.

The specific objectives were: i) to determine the chromosome number of populations collected from different vegetation types under different conditions of rainfall, temperature, altitude, and soil types, aiming to correlate environmental patterns with chromosome numbers; and ii) to determine similarities in environmental factors at the sites of diploid and polyploid populations.

Genetics and Molecular Research 15 (4): gmr15048842 
R.M. Silveira et al.

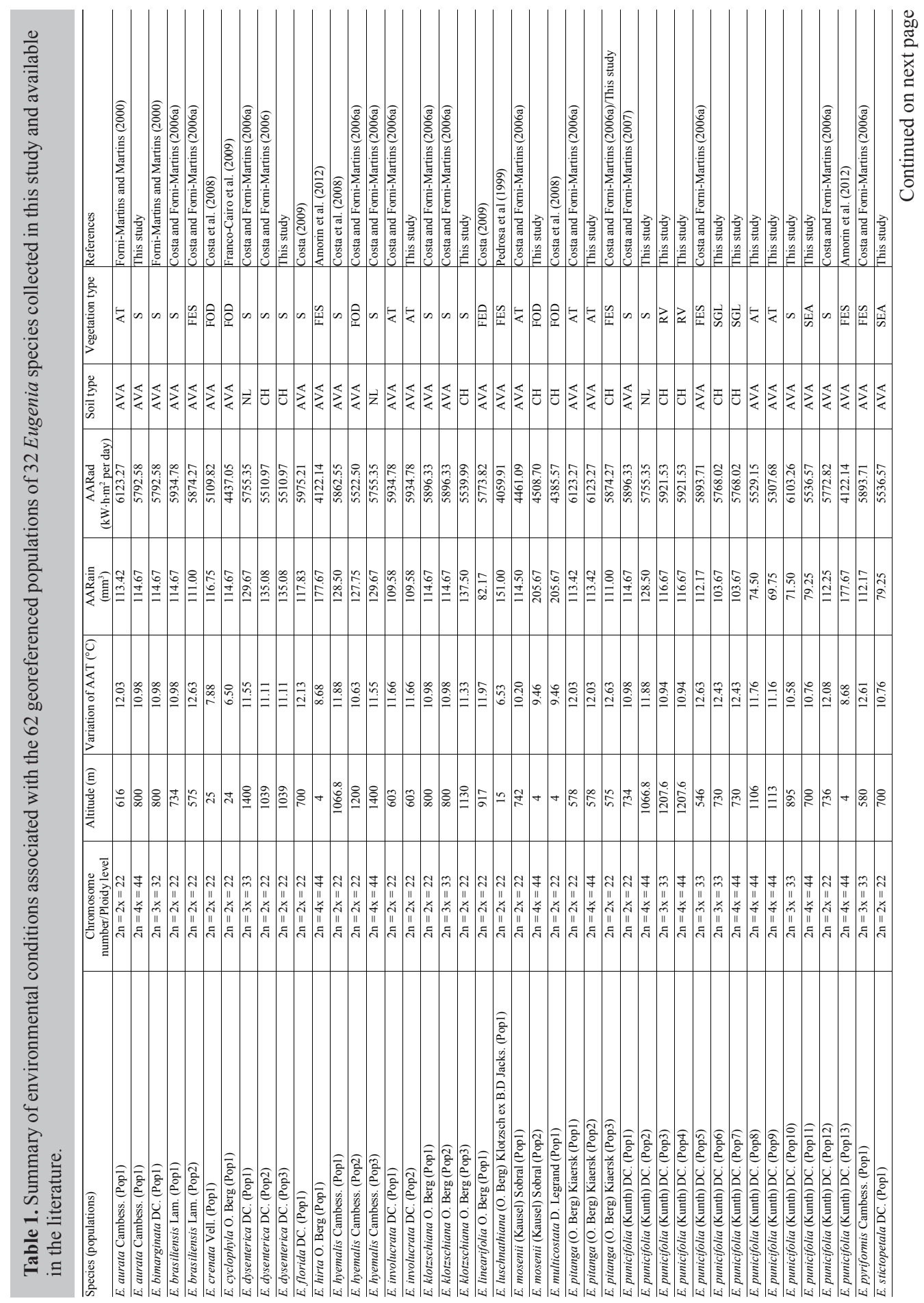

Genetics and Molecular Research 15 (4): gmr15048842 


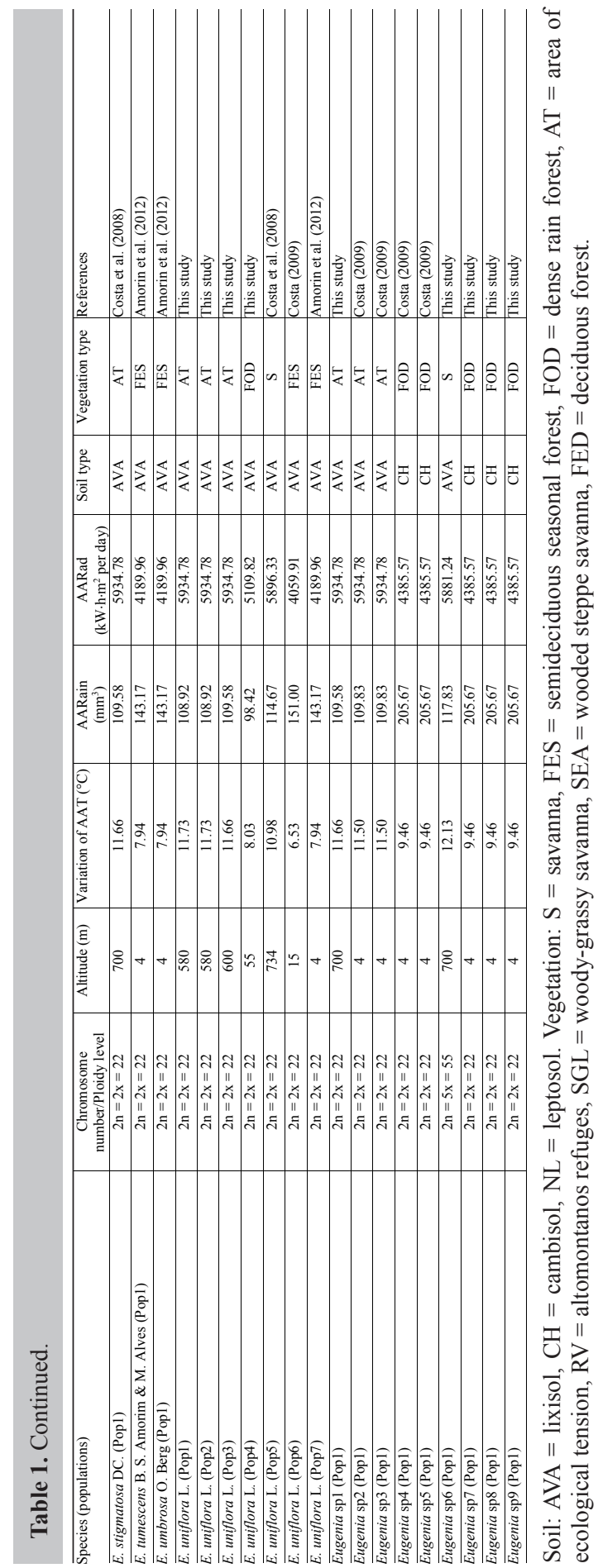

Genetics and Molecular Research 15 (4): gmr15048842 


\section{MATERIAL AND METHODS}

\section{Material collection}

Biological material (roots or seeds) was collected from the eastern region of Brazil, including areas in the states of Ceará, Bahia, Minas Gerais, São Paulo, Rio de Janeiro, and Federal District. Voucher materials of these collections are deposited in the Herbarium UEC (Universidade Estadual de Campinas) and in the Herbarium EAC (Universidade Federal do Ceará).

\section{Chromosome counts and literature review}

To obtain mitotic metaphases, seeds were germinated at $28^{\circ}-30^{\circ} \mathrm{C}$. Root tips were pretreated with $2 \mathrm{mM} 8$-hydroxyquinoline for $24 \mathrm{~h}$, at $8^{\circ} \mathrm{C}$ and fixed in Farmer's solution (Costa and Forni-Martins, 2006, 2007). For slide preparation, samples were frozen $\left(-20^{\circ} \mathrm{C}\right)$ and stained using the Giemsa technique (Guerra, 1983). The slides were examined by light microscopy, and meiotic and mitotic cells with good chromosome condensation and spreading were photographed with a photomicroscope. We searched the literature for chromosome numbers/ploidy levels of other Eugenia species/populations (Table 1).

\section{Collection and analysis of environmental variables}

For all the populations analyzed here and obtained from the literature review, we collected data on ploidy levels and produced maps of ploidy distribution using the DIVAGIS software 7.5 (Hijmans et al., 2012). For each collection site, we recorded temperature, rainfall, and altitude data.

Climate information available in DIVA-GIS for each population was organized in Excel spreadsheets for statistical analyses. Solar radiation data were extracted from shapes plotted in DIVA-GIS available at the National Organization for Environmental Data System (PROBE) site (http://sonda.ccst.inpe.br/publicacoes/atlas_solar.html). Similarly, data on soil and vegetation were extracted from shapes plotted in DIVA-GIS available at the Brazilian Institute of Geography and Statistics (IBGE) site (http://mapas.ibge.gov.br/tematicos/).

The recorded environmental variables were analyzed in R. Data on environmental variables were divided into two groups, namely, those associated with polyploid and diploid populations. Polyploids and diploids were examined to determine the similarity of environmental conditions under which they occur. Non-parametric tests were used to determine the significance of these differences, since the data were not normally distributed (Morettin and Bussab, 2010).

The Wilcoxon-Mann-Whitney test was used to compare mean and median altitude, annual rainfall, rainfall in the rainy and dry periods, annual direct radiation and radiation in the seasons, annual temperature variation (maximum and minimum temperature), and temperature variation in summer, fall, winter, and spring. Chi-squared test was used to construct a graph showing the frequency distribution of soil types of polyploids and diploids and to determine the significance of any differences.

We applied principal component analysis (PCA) to determine the environmental conditions most correlated with the occurrence of polyploids and diploids.

Genetics and Molecular Research 15 (4): gmr15048842 


\section{RESULTS}

\section{Chromosome counts and ploidy distribution}

The chromosome numbers of 26 populations of 14 different Eugenia species were determined (Table 1 and Figure 1). There were 13 polyploid populations, of which three showed a ploidy level equal to $2 \mathrm{n}=3 \mathrm{x}=33$, nine populations showed a ploidy level equal to $2 n=4 x=44$, and one population was pentaploid $(2 n=5 x=55)$. Note that two populations of E. punicifolia showed polyploid sympatric speciation (pop5 and pop6). There were 13 diploid populations with chromosome number equal to $2 \mathrm{n}=2 \mathrm{x}=22$ (Table 1 ).

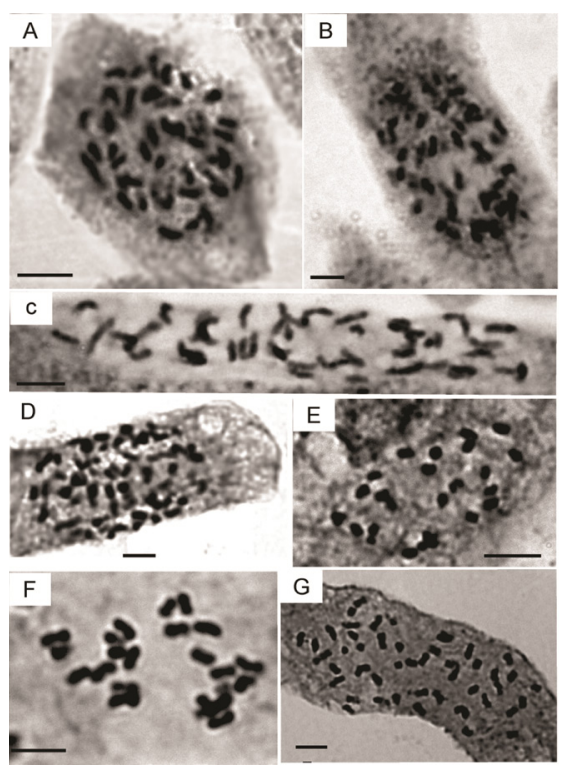

Figure 1. Mitotic metaphase of Eugenia species. A. Eugenia punicifolia (3x). B. E. pitanga (4x). C. E. punicifolia (4x). D. Eugenia sp6 (5x). E. E. uniflora (2x). F. E. stictopetala (2x). G. E. mosenii.

Our data, along with that published in the literature, show that the following Eugenia species had diploid (2x) and polyploid cytotypes (4x): E. aurata O. Berg, E. hyemalis, E. mosenii (Kausel) Sobral, and E. pitanga. E. dysenterica and E. klotzschiana presented cytotypes $2 \mathrm{x}$ and $3 \mathrm{x}$, while E. punicifolia had three cytotypes $(2 \mathrm{x}, 3 \mathrm{x}$, and $4 \mathrm{x})$. A further four species showed only one polyploid number: E. bimarginata $(2 \mathrm{n}=3 \mathrm{x}-1=32)$, E. pyriformis $(2 \mathrm{n}$ $=3 \mathrm{x}=33)$, E. hirta $(2 \mathrm{n}=4 \mathrm{x}=44)$, and Eugenia sp6 $(2 \mathrm{n}=5 \mathrm{x}=55)($ Table 1$)$.

Maps showing the geographical distribution of polyploids and diploids generated in DIVA-GIS are shown in Figure 2. A total of 62 populations of 32 Eugenia species are plotted.

Polyploid cytotypes showed a distinct geographical distribution to diploid cytotypes (Figure 2), occurring more frequently in high-altitude areas. Some populations showed diploid and polyploid cytotypes in sympatry, such as E. klotzschiana and E. pitanga. In those populations, we identified individuals with diploid and polyploid chromosome numbers within the same population. Given the high number of populations, E. punicifolia was analyzed separately. 

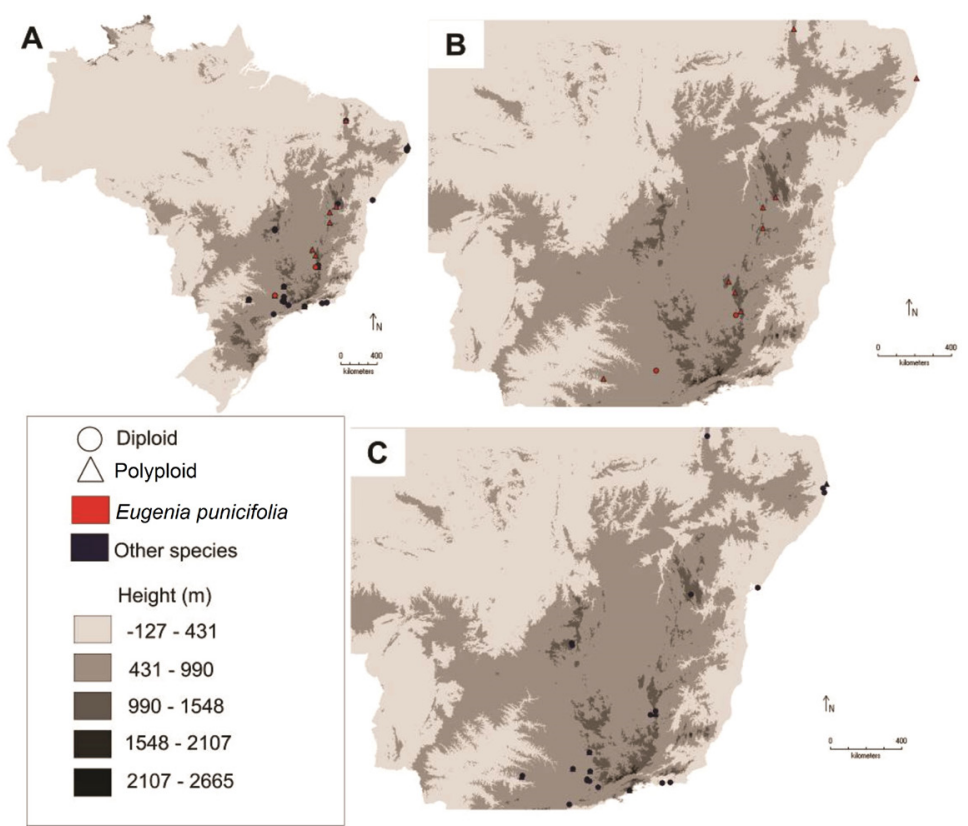

Figure 2. Distribution map of populations of Eugenia species. A. Diploid populations are represented by circles and polyploid populations are represented by triangles. B. Populations of E. punicifolia; diploid populations are represented by red circles and polyploid populations are represented by red triangles. C. Populations of other Eugenia species; diploid populations are represented by blue circles and polyploid populations by blue triangles.

\section{Environmental variables x ploidy levels}

The pattern of environmental factors under which polyploids occur was significantly different from that of diploids, as described in Table 1. Here, we present the results for each environmental feature.

\section{Altitude}

Altitude data for polyploid and diploid populations were compared. The central tendency (median and mean) of altitude of polyploid populations was significantly different and greater than the median altitude of diploids $(\mathrm{W}=240, \mathrm{P}<0.05)$. The boxplot in Figure 3 shows the median value and the distribution of altitude values for diploid and polyploid populations.

\section{Annual temperature variation}

Variation in the annual temperature (maximum minus the minimum temperature of each month for each population) was compared between diploids and polyploids. Variation in the annual temperature at sites of polyploid occurrence was significantly different and higher than that of diploids $(\mathrm{W}=67002.5, \mathrm{P}<0.05)$. A boxplot of the data on annual temperature variation illustrates this difference (Figure $4 \mathrm{~A}$ ).

Genetics and Molecular Research 15 (4): gmr15048842 


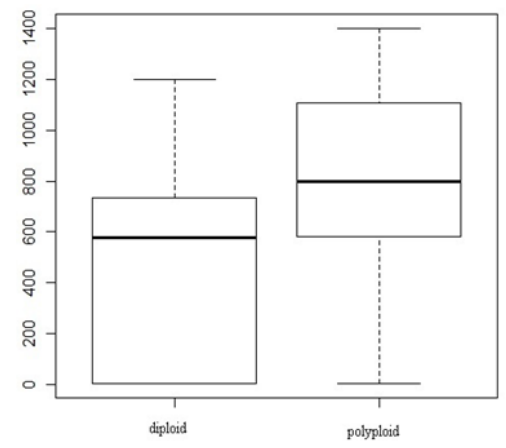

Figure 3. Boxplot of altitude of diploids and polyploids from all populations of Eugenia sampled in this study.

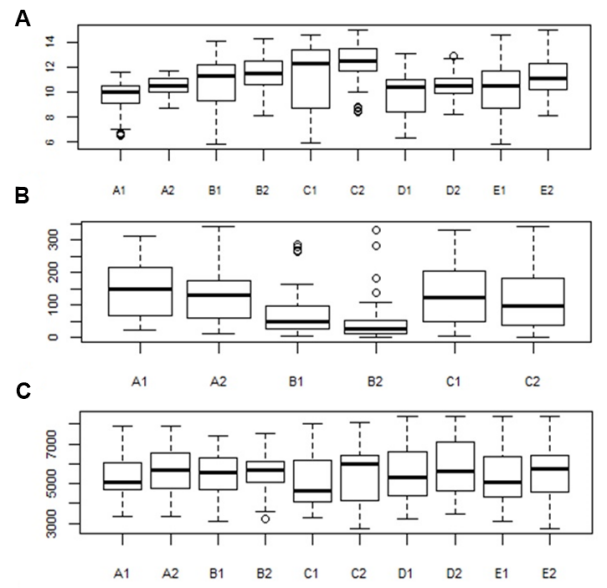

Figure 4. Boxplot showing temperature variation $(\mathbf{A})$ over the seasons $(\mathrm{A}=$ summer; $\mathrm{B}=$ autumn; $\mathrm{C}=$ winter; $\mathrm{D}=$ spring $)$ and along the year $(\mathrm{E})$. Numbers represent the ploidy level $(1=$ diploid; $2=$ polyploid $)$; $\mathbf{B}$. rainfall in the rainy (A) and dry (B) periods and along the year (C). Numbers represent the ploidy level $(1=$ diploid; $2=$ polyploid). C. Direct solar radiation over the seasons ( $\mathrm{A}=$ summer; $\mathrm{B}=$ autumn; $\mathrm{C}=$ winter; $\mathrm{D}=\operatorname{spring})$ and along the year $(\mathrm{E})$. Numbers represent the ploidy level $(1=$ diploid; 2 = polyploid $)$.

\section{Annual rainfall}

Annual rainfall (rainfall data for each month throughout the year) was compared between diploids and polyploids. There were significant differences in the annual rainfall between groups $(\mathrm{W}=67152.5, \mathrm{P}<0.05)$. Figure 4B shows that polyploids experience lower rainfall throughout the year.

\section{Rainfall in the rainy period}

Rainfall in the rainy and dry periods was analyzed to consider variations in rainfall throughout the year (Figure 4B). Comparison of rainfall in the rainy period between diploids and polyploids indicated there were no significant differences $(\mathrm{W}=7733.5, \mathrm{P}=0.05307)$. The rainiest period corresponded to the summer months. 


\section{Rainfall in the dry period}

Rainfall in the dry period was significantly lower for polyploids ( $\mathrm{W}=9430.5, \mathrm{P}<$ 0.05). The driest period corresponded to the winter months (Figure 4B).

\section{Annual direct solar radiation}

Solar radiation reaching the Earth surface, or direct radiation, was analyzed and values throughout the year were compared between diploids and polyploids. Differences between the groups were significant $(\mathrm{W}=50329.5, \mathrm{P}<0.05)$. The boxplot shows that polyploid populations receive higher levels of radiation throughout the year (Figure 4C).

\section{Soil classes}

Soil classes were analyzed herein as an environmental variable. Soil types on which diploids occurred were lixisol and cambisol (Table 1 and Figure 5A). Diploid populations of Eugenia occurred on lixisol (77.5\%) and cambisol (22.5\%). Polyploids were found on three classes of soil, lixisol (61\%), cambisol (24\%), and leptosol (14\%) (Table 1 and Figure 5A).

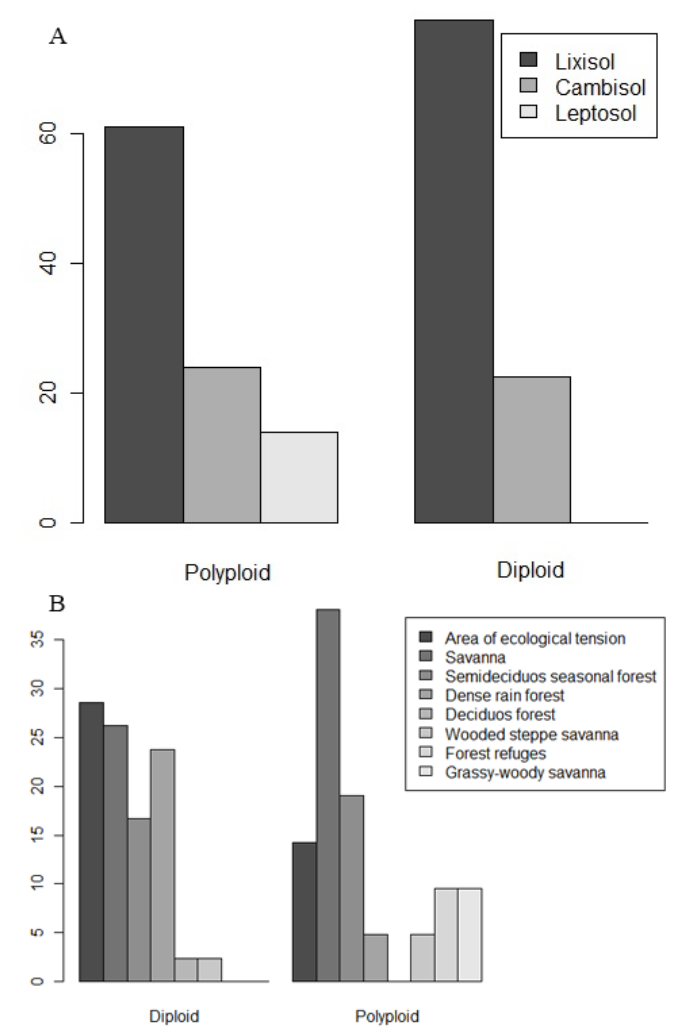

Figure 5. Barplot of percentage of diploid and polyploid populations (A) occurring on different soil types, and percentage of vegetation types of diploid and polyploid populations (B).

Genetics and Molecular Research 15 (4): gmr15048842 
The frequency observed for each soil class was compared between diploids and polyploids. The differences between the expected and observed frequencies of polyploids and diploids were significant for the class leptosol (chi-squared $=14, \mathrm{P}<0.05$ ). This difference is visualized in the barplot for the leptosol class (Figure 5A).

\section{Vegetation types}

The types of vegetation in which Eugenia species occur and the frequency of diploid and polyploid distribution are presented in Table 1 and Figure 5B. The difference between the observed and expected frequency between polyploids and diploids was significant for the following vegetation types: savanna (chi-squared $=4.0114, \mathrm{P}<0.05$ ), area of ecological tension (transition areas) (chi-squared $=4.1831, \mathrm{P}<0.05$ ), dense rain forest (chi-squared $=13.7654, \mathrm{P}<0.05)$, grassy-woody savanna $(\mathrm{Chi}$-squared $=9.52, \mathrm{P}<0.05)$, and highland refuges (chi-squared $=9.52, \mathrm{P}<0.05$ ). Polyploids were more frequent in savannas, whereas diploids were mainly collected in transition areas between savanna and tropical rain forest.

Figure 6 illustrates the distribution of all analyzed data (Figure 6). The relationship between ploidy and those variables described above are presented graphically. The effect of altitude on the other variables is also shown. At high altitudes, temperature and rainfall decrease while radiation increases (Figure 6). The PCA separated the populations into four groups (Figure 7A). The groups were formed according to the quantitative environmental variables analyzed. Populations closest geographically and under similar environmental conditions were located within the same quadrant (Figure 7B).

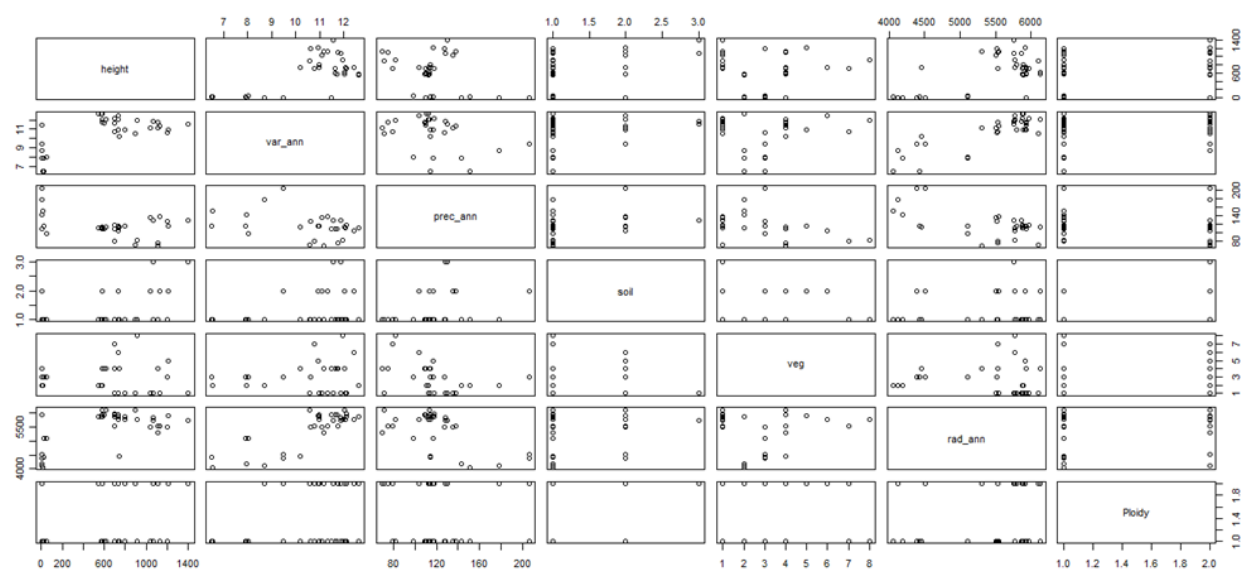

Figure 6. Scatterplot of the matrix containing data on environmental variables. Annual rainfall (prec_ann), annual temperature variation (var_ann), vegetation types (veg), annual radiation (rad_ann). Qualitative variables: Ploidy: (1) diploid - 2x (2) polyploidy - 3x, 4x or 5x. Vegetation: 1) savanna, 2) semideciduous seasonal forest, 3) dense rain forest, 4) area of ecological tension, 5) forest refuges, 6) grassy-woody savanna, 7) wooded steppe savanna, 8) deciduous forest. Soil type: 1) lixisol, 2) cambisol, 3) leptosol.

Quantitative environmental variables influenced the distribution of Eugenia species the most, since axis 1 was formed by those variables and explained $60 \%$ of the data variability. In the PCA ordination graph, the most similar populations were located close to each other. The distribution of polyploids was mainly associated with altitude (Figure 8).

Genetics and Molecular Research 15 (4): gmr15048842 

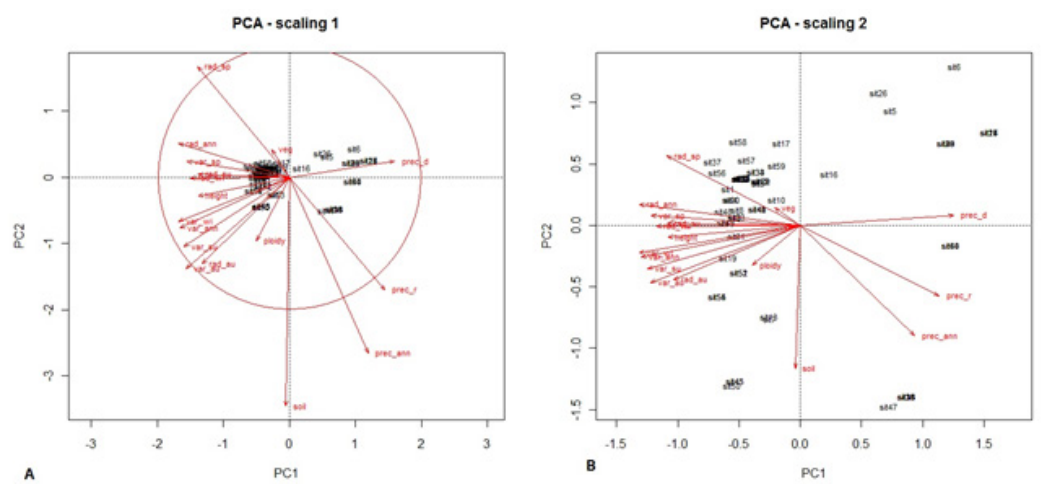

Figure 7. Principal component analysis (PCA): A. Separation of Eugenia populations into four groups. B. Populations with associated variables.

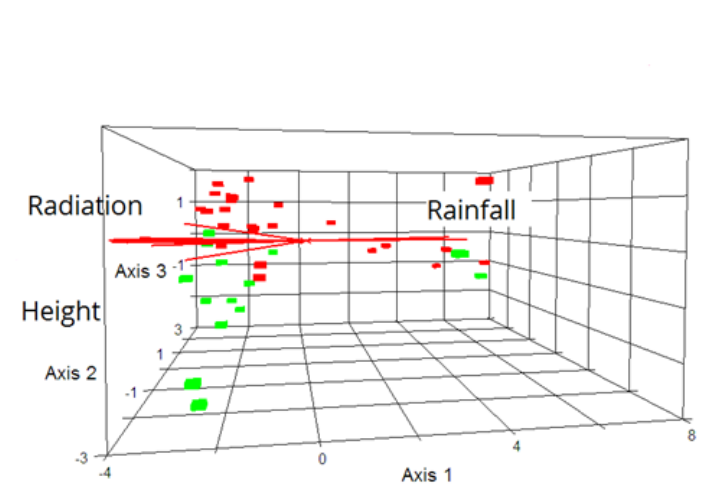

Figure 8. Arrangement of Eugenia populations (represented by parallelepipeds) according to the variables (represented by red lines). Ploidy level: (1) diploid, (2) polyploid.

\section{DISCUSSION}

We recorded only one unpublished chromosome number, $2 \mathrm{n}=2 \mathrm{x}=22$ for $E$. stictopetala DC. (Table 1), and we found several records of ploidy levels until no recorded as for species E. aurata, E. mosenii, and E. punicifolia (Table 1). For some populations, the records are consistent with the findings of Costa and Forni-Martins $(2006,2007)$.

Generally, polyploid and diploid populations exhibited distinct spatial distribution patterns, which were related to different environmental conditions. The species that showed polyploid cytotypes, mainly E. punicifolia, have a wide geographical distribution, and occur in different types of soil and vegetation, at high altitudes and high radiation, and under a wide range of temperature and rainfall conditions. Polyploid cytotypes of other species occurred in regions differing in at least one environmental factor in relation to the diploid cytotypes.

The occurrence of polyploid cytotypes in sites with environmental conditions different from those found where diploids occur, indicates that polyploids exhibit environmental tolerance for those factors, unlike diploids of certain species. Thus, in general, considering the diploid and polyploid cytotypes, this species has increased environmental tolerance due to polyploidy.

Genetics and Molecular Research 15 (4): gmr15048842 
Broad environmental tolerance allows the species to colonize and settle in different locations, which tends to expand the geographical distribution of the species. Populations subjected to different selection pressures start to accumulate genetic and phenotypic differences. This diversification process, via the production of polyploid cytotypes, is responsible for the classification of cytotypes into infraspecific categories, due to difficulties in species identification (Schifino-Wittmann, 2004).

Researchers use the term "robust" to describe the ability of polyploid individuals to colonize and settle under conditions that are adverse for diploid individuals of the same species (de Wet, 1980). Conditions are considered adverse if they do not allow the establishment of diploids. The genetic robustness of polyploids is explained by the high genetic variability in these individuals due to the high number of chromosomes. In addition, chromosomes of different species can sometimes become activated in the genome (Osborn et al., 2003; Soltis et al., 2010).

The high genetic variability responsible for polyploid "robustness" results in wide ecological tolerance. This explanation can be applied to species of Eugenia. Polyploidy increased the environmental tolerance of the species for at least one environmental factor. $E$. punicifolia had the largest number of polyploid cytotypes; for this species, polyploidy resulted in the formation of triploid and tetraploid cytotypes. It is not coincidental that this was the most diverse species in relation to environmental conditions under which its populations occurred. E. punicifolia was found in seven vegetation types, three soil types, at altitudes from $4 \mathrm{~m}$ to over $1300 \mathrm{~m}$. The populations were found in sites where temperature varied by more than $12^{\circ} \mathrm{C}$, on average, and both in drier $\left(77 \mathrm{~mm}^{3}\right)$ and wetter $\left(177 \mathrm{~mm}^{3}\right)$ regions.

In addition, this species is difficult to identify, given the morphological variation among individuals of the same species, resulting in many synonyms (Sobral et al., 2016). The species has polyploid populations, which exhibit morphological differences and occur in different places, resulting in its wide distribution in Brazil. Thus, it is likely that polyploidy was involved in the evolutionary history of this species. Morphological differences between different ploidy levels resulted from genetic differences. However, it remains unclear how such differences affect the spatial distribution of cytotypes (Johnson et al., 2003). The explanation suggested herein is that ecological and genetic variations contribute to the establishment of polyploids (Husband, 2000), thus permitting the spread of species with different levels of ploidy. The mechanism is that seen previously, termed as diversification via the formation of polyploid cytotypes.

The genetic variability of polyploids, translated ecologically into broad environmental tolerance, enabled the establishment and maintenance of populations in regions with different environmental conditions. Different environmental factors represent different selection pressures that act on the population, which along with high genetic variability, are responsible for their diversification (Begon et al., 2007). E. punicifolia illustrates the pattern found in the analysis of 62 populations of Eugenia in this study, which supports the initial hypothesis.

\begin{abstract}
Altitude
We noted differences in altitude between diploid and polyploid populations, since the climatic conditions of high altitude regions are different from those of low-altitude regions (Azócar et al., 2007). In this way, if the altitudes differ, other environmental factors would also differ. This shows that polyploids occur at higher altitudes than diploids. At high altitudes, environmental conditions are considered to be more severe (Mocochinski, 2006), and the ability to survive these environmental factors differs from low altitude regions. Consequently, for a
\end{abstract}

Genetics and Molecular Research 15 (4): gmr15048842 
species occurring at low altitudes to survive and establish in high altitude regions, it must have broad environmental tolerance to environmental factors that change depending on the altitude.

\section{Temperature}

Temperature is an environmental condition that changes at high altitudes (Sakai and Larcher, 1987). In high altitude regions, the minimum temperature is low, and there is little variation between seasons. Conversely, there is large variation in daily temperature (Table 1). Thus, altitude is an important variable with respect to the distribution limits of plant species since not all species can support rapid changes in temperature or lower temperatures. Polyploid populations that occur in areas of high altitude support larger variations in temperature than diploid populations. Polyploidy increased the limits of temperature supported by species by extending the tolerance to low temperatures and daily temperature variations. The increase in thermal amplitude may influence several physiological processes, such as photosynthesis, with effects on the ecological characteristics of the species, including the time of germination (Mondo et al., 2010). The effect observed in this study was that the polyploid cytotypes, when found at a high altitude, expanded the geographical distribution of the species.

\section{Rainfall}

Rainfall governs plant development. Many plant species do not tolerate water stress in response to both excess and lack of water in the soil (Sá et al., 2004). Thus, the amount and distribution of rainfall throughout the year in a region limits the establishment of plant species. Polyploid populations can occur under conditions of lower rainfall than diploid populations. In both dry and rainy periods, the amount of rainfall was significantly lower where polyploids occurred. The lowest amount of rainfall is positively correlated to lower water availability for plants (Krupek and Fritz, 2011). For plants to survive under conditions of low water availability, several physiological, morphological, and developmental changes are triggered (Nepomuceno et al., 2001). Those changes derive from the plant's genetic repertoire and as polyploids have high genetic variability, they are able to tolerate environments where rainfall is lower. Thus, polyploid populations were found in places with greater water scarcity compared with diploid populations, which increases the tolerance of species to this environmental factor.

\section{Radiation}

The level of radiation influences the distribution of plant species, since light energy is converted into chemical energy, which drives metabolic processes in the plant (Zeiger and Taiz, 2006). Plants differ in their tolerance to radiation levels, which is understandable in view of their importance to plant survival (Zeiger and Taiz, 2006). Additionally, some plants exist that tolerate larger or smaller levels of radiation. Researchers use the terms sun plants and shade plants to refer to the ability of individuals to survive under higher or lower levels of light energy, respectively. Increased tolerance to radiation is an adaptive trait that be advantageous for the species. In the present study, the amount of direct radiation received by polyploid populations was significantly greater than that received by diploid populations. This indicates that polyploid cytotypes are able to withstand higher levels of radiation, which extends the limits of environmental tolerance to this factor. The ability to support higher levels of radiation

Genetics and Molecular Research 15 (4): gmr15048842 
allows polyploids to establish in open areas, where the amount of light reaching the plants is higher, such as grasslands and fields, which was confirmed in the present study.

\section{Soil types}

Plants take nutrients and water from the soil. However, soils differ in their physical and chemical structure, the amount and size of the clumps, and in the proportion of chemical elements, organic matter, and humus. These factors alter the amount and availability of nutrients and water. Consequently, plants have adaptations and specializations permitting their occurrence in certain types of soil (Benites et al., 2003). Comparison between the expected and observed frequencies of polyploid and diploid populations on different soil types indicated that they differ in relation to the class leptosol. Leptosols are a class of underdeveloped soils in relation to pedogenetic processes (Jacomine, 2009). In this sense, the mechanical structure of this soil and its physical and chemical characteristics differ in relation to cambisol and lixisol.

The soil thickness does not exceed $0.50 \mathrm{~m}$ (Mocochinski, 2006), which may limit root growth, especially tap roots. The concentration of nutrients, such as phosphorus, and water availability may be low, which also limits plant growth. Thus, the conditions provided by this type of soil restrict the establishment of plant species and may be considered adverse (Benites et al., 2003). The establishment of plants on leptosol requires the adaptation of individuals to specific conditions. Such adaptations are present in polyploids, which were the only plants found in this type of soil. Thus, polyploidy increased the environmental tolerance to soil, permitting the occurrence of species in different types of soil.

\section{Type of vegetation}

Plants make up different vegetation types, which differ in the dominance of life forms, density of individuals, leaf lifespan, structure, and physiognomy (Coutinho, 2005). Those differences reflect the main limiting physical factors such as climate, soil, and fire (Coutinho, 2005). Polyploid populations of Eugenia have been able to establish in vegetation types different to those used by diploid cytotypes. In cases where diploids and polyploids occurred in the same type of vegetation, there were differences in the altitude, soil type, or amount of radiation. In this way, the occurrence of a species in more than one type of vegetation is indicative of wide environmental tolerance, particularly if the types of vegetation are found in environments that differ with respect to other factors that influence plant establishment.

Polyploid cytotypes were more frequent in savannas. Considering the occurrence frequencies in savanna (38.09\%), wooded steppe savanna $(9.52 \%)$, and grassy-woody savanna $(9.52 \%)$, about $57 \%$ of polyploid cytotypes were found in this environment. The observed frequencies of polyploids and diploids differed significantly from the expected frequencies. Polyploids occur in savanna more frequently than would be expected by chance, as well as in grassy-woody savanna vegetation in which only polyploid populations were collected.

Diploid populations occur more frequently in areas of ecological tension between savanna and rain forest $(27.5 \%)$. Areas of ecological tension are regions containing two types of vegetation (IBGE, 2004). These areas are common in the Cerrado biome, considered to be a mosaic of vegetation types, representing the area from where most of the diploid species were collected. The observed frequency of diploids collected in areas of ecological tension and dense rain forest were significantly higher than the observed frequency of polyploids.

Genetics and Molecular Research 15 (4): gmr15048842 
The division of groups in the PCA reflects the region of occurrence of the population, thus populations present in regions with similar environmental conditions are grouped together. Both the diploid and polyploid populations collected in the northeastern region, and in coastal regions, were influenced by rainfall. Populations collected in the northeast were influenced by rainfall during the dry period, and populations collected on the coast were grouped by similarities in annual rainfall and in the rainy period. Polyploid populations collected in the southeastern and central-western region, were grouped by altitude, while diploid populations collected in this region responded mainly to similarities in radiation.

Moreover, environmental variables affecting each group correspond to the most prominent characteristic of each region, which showed similar variance between components. The northeast region presents low rainfall and long periods of drought, such that rainfall in the dry period was the main variable influencing the components of this group. Polyploids of southeastern and central-western regions were collected at high altitudes, consequently, this was the variable most closely associated with these populations.

Populations located near the coast, in dense rain forests, have high levels of rainfall. In this way, the annual rainfall and that in the rainy period were the variables most associated with populations of this group. We found diploid populations collected in the southeastern and central-western regions in forested areas, which determine the entry of radiation; therefore, this was the variable that most influenced the representatives of this group.

\section{Environmental distribution pattern}

Diploids were found in vegetation types typical of milder climates, with high rainfall levels, low temperature variation, deep soil types, and appropriate structural, chemical, and physical conditions for large trees. Large vegetation affects the levels of radiation reaching the surface. Forested areas have low albedo (surface reflection coefficient), which decreases the amount of radiation that reaches the surface and is reflected. As described, radiation received by diploids was lower than that received by polyploids. This was due to increased cloud cover and rainfall in those areas (Pereira et al., 2006). Therefore, environmental factors affecting sites where diploids occur are mild.

Conversely, polyploids were found in savanna vegetation, in which plants are of smaller size and the trees are more scattered, contributing to a higher incidence of radiation on the surface, in addition to the altitude increase. The climate was more adverse, the temperature variation between seasons and over the year was greater, reaching $15^{\circ} \mathrm{C}$ in a few months. Water availability was lower given the low level of rainfall, the slope of the area, typical of mountain regions and the soil type, especially for the absence of mechanical structure for water storage, such as cambisol and lixisol.

Even cambisol and lixisol in high slope regions, such as populations collected at high altitudes, are leached and eroded by rainwater, leading to a lack of nutrients and water, and a change in the shape and size of the clumps causing defects in the mechanical structure of the soil. Given the high genetic variability, polyploidy established in environments where conditions are more adverse. From an ecological point of view, polyploidy extended the limits of environmental tolerance of the species.

Genetics and Molecular Research 15 (4): gmr15048842 


\section{Spatial distribution pattern}

The spatial distribution pattern of polyploids followed an altitudinal gradient. To understand this result, it is sufficient to know that the climate changes according to altitude, that is, the higher the altitude, the more adverse the conditions. As polyploids are more robust than diploids, they tolerate these environmental conditions, increasing their frequency with increasing altitude. Additionally, climate changes in a similar way, depending on both altitudinal and latitudinal gradients. In this sense, the spatial distribution of polyploids worldwide can be understood by their environmental tolerance. The environmental tolerance may also explain the separation between cytotypes of species.

In conclusion, polyploidy is very frequent in Eugenia $(\mathrm{x}=11)$, and there are both diploid $(2 \mathrm{n}=2 \mathrm{x}=22)$ and polyploid $(2 \mathrm{n}=3 \mathrm{x}=33,2 \mathrm{n}=4 \mathrm{x}=44$ and $2 \mathrm{n}=5 \mathrm{x}=55)$ species. Some species showed diploid and polyploid cytotypes, such as E. aurata, E. hyemalis, E. mooseni, and E. pitanga (2x and 4x), E. dysenterica and E. klotzschiana (2x and 3x), and E. punicifolia $(2 \mathrm{x}, 3 \mathrm{x}$, and $4 \mathrm{x})$. The cytogeographical analysis applied to 32 species and 62 populations revealed a different spatial distribution pattern and the existence of different environmental conditions according to the level of ploidy. Polyploidy allows the occurrence of species at locations where environmental conditions have a wide range of variation. Polyploid individuals are usually found at higher altitudes and under more adverse environmental conditions (large temperature variation, low amount of rainfall and great water scarcity, large level of radiation, underdeveloped soils, and open vegetation, such as savanas). Thus, species with diploid and polyploid cytotypes had a broader environmental tolerance, and occurred under different environmental conditions, altitude, soil types. and vegetation.

\section{Conflicts of interest}

The authors declare no conflict of interest.

\section{ACKNOWLEDGMENTS}

We thank Carolyn Proença (UnB) and Rafael Carvalho da Costa (UFC) for additional comments. We thank CAPES for providing the Master's scholarship for R.M. Silveira and CNPq - Conselho Nacional de Desenvolvimento Cientifico e tecnológico for providing a Research Fellowships for E.R. Forni-Martins. This study forms part of the Master's dissertation of R.M. Silveira at Programa de Pós-Graduação em Ecologia e Recursos Naturais. Research supported by FUNCAP - Fundação Cearense de Apoio ao Desenvolvimento Cientifico e Tecnológico (Grant \#10582430-5 - Programa Primeiros Projetos) and CNPq (\#479263/20116 - Edital Universal 2011) to Itayguara Ribeiro da Costa; FAPESP - Fundação de Amparo à Pesquisa do Estado de São Paulo (Grant \#04/13041-8 and \#01/13169-6) and CNPq (Grant \#471065/2004-8) to Eliana Regina Forni-Martins.

\section{REFERENCES}

Aarestrup JR, Karam D and Fernandes GW (2008). Chromosome number and cytogenetics of Euphorbia heterophylla L. Genet. Mol. Res. 7: 217-222. http://dx.doi.org/10.4238/vol7-1gmr421

Genetics and Molecular Research 15 (4): gmr15048842 
Aguiar WM and Gaglianone MC (2012). Euglossine bee communities in small forest fragments of the Atlantic Forest, Rio de Janeiro state, southeastern Brazil (Hymenoptera, Apidae). Rev. Bras. Entomol. 56: 210-219. http://dx.doi. org $/ 10.1590 / \mathrm{S} 0085-56262012005000018$

Amorin BS, Alves M, Guerra G and Souza LGR (2012). IAPT/IOPB chromosome data 14. Taxon 61: 1336-1345.

Azócar A, Rada F and García-Núnez C (2007). Funtional characteristics of the arborescent genus Polylepis along a latitudinal gradient in the high andes. Interciencia 32: 663-668.

Begon M, Townsend CR and Haper JL (2007). Ecologia: de indivíduos a ecossistemas. Porto Alegre: Artmed.

Benites VM, Caiafa NA, Mendonça ES, Schaefer CE, et al. (2003). Solos e vegetação nos complexos ruprestes de altitude da Mantiqueira e do Espinhaço. Floresta Ambient. 10: 76-85.

Costa IR (2009). Estudos evolutivos em Myrtaceae: aspectos citotaxônomicos e filogenéticos em Myrteae, enfatizando Psidium e gêneros relacionados. PhD thesis, Universidade Estadual de Campinas.

Costa IR and Forni-Martins ER (2006a). Chromosome studies in Eugenia, Myrciaria and Plinia (Myrtaceae) from southeastern Brazil. Aust. J. Bot. 54: 409-415.

Costa IR and Forni-Martins ER (2006b). Chromosome studies in Brazilian species of Campomanesia Ruiz \& Pávon and Psidium L. (Myrtaceae Juss.). Caryologia 59: 7-13.

Costa IR and Forni-Martins ER (2007). Chromosome studies in species of Gomidesia, Marlierea, Myrceugenia and Myrcia (Myrtaceae, subtribe Myrciinae). Kew Bull. 62: 113-118.

Costa IR, Dornelas MC and Forni-Martins ER (2008). Evolution of nuclear DNA contents among Neotropical Myrtaceae (fleshy-fruited Myrtaceae). Plant Syst. Evol. 276: 209-217.

Coutinho LM(2005). O conceito de bioma. Acta Bot. Bras. 20: 13-23. http://dx.doi.org/10.1590/S0102-33062006000100002

deWet JMJ (1980). Origins of polyploids. Basic Life Sci. 13: 3-15.

Forni-Martins ER and Martins FR (2000). Chromosome studies on Brazilian cerrado plants. Genet. Mol. Biol. 23: 947955. http://dx.doi.org/10.1590/S1415-47572000000400040

Franco-Cairo JPL, Guedes MLS and Oliveira ALPC (2009). Análises citogenéticas em espécies de Angiospermae de um ecossistema de restinga. Sociedade Brasileira de Genética, São Paulo. Available at [http://web2.sbg.org.br/congress/ sbg2008/pdfs2009/GP.pdf]. Accessed December 14, 2014.

Govaerts R, Sobral M, Ashton P, Barrie F, et al. (2016). World checklist of Myrtaceae. Kew: Royal Botanic Garden. Available at [http://apps.kew.org/wcsp/]. Accessed April 4, 2016.

Guerra M (1983). O uso do Giemsa na citogenética vegetal-comparação entre a coloração simples e o bandeamento. Cienc. Cult. 35: 1661-1663.

Hijmans RJ, Guarino L and Mathur P (2012). DIVA-GIS v. 7.5. 2012. A geographic information system for the analysis of biodiversity data. Available at [http://www.diva-gis.org].

Husband BC (2000). Constraints on polyploid evolution: a test of the minority cytotype exclusion principle. Proc. Biol. Sci. 267: 217-223. http://dx.doi.org/10.1098/rspb.2000.0990

IBGE (2004). Vocabulário básico de recursos naturais e meio ambiente. 2nd edn. IBGE, Rio de Janeiro.

Jacomine PKT (2009). A nova classificação brasileira de solos. Anais da Academia Pernambucana de Ciências Agronômica 6: 161-179.

Johnson MTJ, Husband BC and Burton TL (2003). Habitat differentiation between diploid and tetraploid Galax urceolata (Diapensiaceae). Int. J. Plant Sci. 164: 703-710. http://dx.doi.org/10.1086/376813

Krupek RA and Fritz RB (2011). Avaliação da retenção de água no solo sob diferentes usos na região de Floresta Ombrófila Mista da região centro-sul do Paraná. Ambiência Guarapuava 7: 317-328.

Levin DA (2002). The role of chromosomal change in plant evolution. Oxford: Oxford University Press.

Mocochinski AY (2006). Campos de altitude na Serra do Mar paranaense: aspectos florísticos e estruturais. PhD thesis, Universidade Federal do Paraná.

Mondo VHV, Carvalho SJP, Dias ACR and Filho JM (2010). Efeitos da luz e temperatura na germinação de sementes de quatro espécies de plantas daninhas do gênero Digitaria. Rev. Bras. Sementes 32: 131-137. http://dx.doi.org/10.1590/ $\underline{\text { S0101-31222010000100015 }}$

Morettin PA and Bussab WO (2010). Estatística Básica. 6th edn. Saraiva, São Paulo.

Nepomuceno AL, Neumaier N, Farias JRB and Oya T (2001). Tolerância à seca em plantas: mecanismos fisiológicos e moleculares. Biotecnolog. Cienc. Desenvolv. 23: 12-18.

Osborn TC, Pires JC, Birchler JA, Auger DL, et al. (2003). Understanding mechanisms of novel gene expression in polyploids. Trends Genet. 19: 141-147. http://dx.doi.org/10.1016/S0168-9525(03)00015-5

Otto SP and Whitton J (2000). Polyploid incidence and evolution. Annu. Rev. Genet. 34: 401-437. http://dx.doi.org/10.1146/ annurev.genet.34.1.401

Pedrosa A, Gitaí J, Silva AEB, Felix LP, et al. (1999). Citogenética de angiospermas coletadas em Pernambuco. Acta Bot. Bras. 13: 49-60.

Genetics and Molecular Research 15 (4): gmr15048842 
Pereira EB, Martins FR, Abreu SL and Rüther R (2006). Atlas Brasileiro de Energia Solar. INEP, São José dos Campos. Ramsey J and Schemske DW (1998). Pathways, mechanisms and rates of polyploid formation in flowering plants. Annu. Rev. Ecol. Syst. 29: 467-501. http://dx.doi.org/10.1146/annurev.ecolsys.29.1.467

Risso-Pascotto C, Mendes DV, Silva N, Pagliarini MS, et al. (2006). Evidence of allopolyploidy in Brachiaria brizantha (Poaceae: Paniceae) through chromosome arrangement at metaphase plate during microsporogenesis. Genet. Mol. Res. 5: 797-803.

Sá JS, Cruciani DE and Minami K (2004). Efeitos de inundações temporárias do solo em plantas de ervilha. Hortic. Bras. 22: 50-54. http://dx.doi.org/10.1590/S0102-05362004000100010

Sakai A and Larcher W (1987). Frost survival of plants. Responses and adaptation to freezing stress. Ecological Studies. Springer, New York.

Schifino-Wittmann MT (2004). Poliploidia e seu impacto na origem e evolução das plantas silvestres e cultivadas. Rev Bras Agrociênc. 10: 151-157.

Sobral M, Proença C, Souza M, Mazine F and Lucas E (2016). Myrtaceae in Lista de Espécies da Flora do Brasil. Jardim Botânico do Rio de Janeiro. Available at [http://floradobrasil.jbrj.gov.br/jabot/floradobrasil/FB10338]. Accessed January 18, 2016.

Soltis DE, Buggs RJA, Doyle JJ and Soltis PS (2010). What we still don't know about polyploidy. Taxon 59: 1387-1403.

Thompson JN, Nuismer SL and Merg K (2004). Plant polyploidy and the evolutionary ecology of plant/animal interactions. Biol. J. Linn. Soc. Lond. 82: 511-519. http://dx.doi.org/10.1111/j.1095-8312.2004.00338.x

Via S, Gomulkiewicz R, De Jong G, Scheiner SM, et al. (1995). Adaptive phenotypic plasticity: consensus and controversy. Trends Ecol. Evol. (Amst.) 10: 212-217. http://dx.doi.org/10.1016/S0169-5347(00)89061-8

Zeiger E and Taiz L (2006). Fisiologia Vegetal. Artmed, Porto Alegre.

Genetics and Molecular Research 15 (4): gmr15048842 